\title{
Pengaruh Pemberian Aditif dalam Ransum Berupa Kombinasi Kulit Singkong dengan Lactobacillus Sp. terhadap Kualitas Eksterior Telur Puyuh Periode Laying
}

\author{
The Effect of Giving Additive in Diet with Combination of Cassava Peel and Lactobacillus Sp. \\ on the Exterior Quality of Laying Period Quail Egg
}

\section{R. A. G. A. S. Putri, E. Suprijatna dan D. Sunarti}

Departemen Peternakan, Fakultas Peternakan dan Pertanian, Universitas Diponegoro Kompleks drh. R.Soejono Koesoemowardojo, Kampus Undip Tembalang, Semarang, 52075 Corresponding email : edjengs@gmail.com

\begin{abstract}
The purpose of this research was to determine the effect of additives supplementation in diet from combination of cassava peels and Lactobacillus sp.to the exterior quality of quail eggs on laying period. The materials used 240 quails 4 -week-old layers, distribute into 4 treatments with 6 replications, each replications has 10 quails. The experimental design used was Completely Random Design (CRD), the level of treatments has given, T0 : basal diet (control), T1: diet + additive $100 \mathrm{ml} / \mathrm{kg}$ diet, T2 : diet + additive $150 \mathrm{ml} / \mathrm{kg}$ diet, T3 : diet + additive 200 $\mathrm{ml} / \mathrm{kg}$ diet. The data were analized with analyze of variance at level significant $5 \%(\mathrm{P}<0.05)$ and will be continued with Multiple Range Test (MRT) Duncan. The results sowed that additives were added to cassava peel with Lactobacillus sp. in quail's diet significantly $(\mathrm{P}<0.05)$ increase egg weight and eggshell thickness. The treatment didn't significantly affected the calcium content of eggshell. The conclusion of this research is giving additive from combination of cassava peels with Lactobacillus $s p$. in solution can increase exterior quality of quail eggs on laying period starting at level $100 \mathrm{ml} / \mathrm{kg}$ diet.
\end{abstract}

Key words : Quail, additive, cassava peel, Lactobacillus sp., exterior quality of egg.

\begin{abstract}
ABSTRAK
Tujuan penelitian ini adalah untuk mengetahui pengaruh pemberian aditif dalam ransum berupa kombinasi kulit singkong dan Lactobacillus sp. pada kualitas eksterior telur puyuh. Materi yang digunakan yaitu 240 ekor puyuh petelur berumur 4 minggu yang didistribusikan kedalam 4 perlakuan dengan 6 kali ulangan, tiap ulangan 10 ekor puyuh. Perlakuan yang diterapkan pada penelitian ini yaitu berupa pemberian aditif dalam ransum berupa kombinasi kulit singkong dan Lactobacillus $s p$. dalam bentuk larutan. Rancangan percobaan yang digunakan yaitu Rancangan Acak Lengkap (RAL). Taraf perlakuan yang diberikan; T0 : Ransum basal (kontrol), T1 : Ransum + aditif $100 \mathrm{ml} / \mathrm{kg}$ ransum, T2 : Ransum + aditif $150 \mathrm{ml} / \mathrm{kg}$ ransum, T3 : Ransum + aditif $200 \mathrm{ml} / \mathrm{kg}$ ransum. Data yang diperoleh dianalisis menggunakan analisis ragam pada taraf signifikansi $5 \%(\mathrm{P}<0,05)$ dan dilanjutkan dengan uji wilayah ganda Duncan. Hasil penelitian menunjukkan bahwa penambahan aditif berupa kulit singkong yang dikombinasikan dengan Lactobacillus sp. dalam ransum puyuh berpengaruh nyata $(\mathrm{P} \leq 0,05)$ meningkatkan bobot telur dan tebal kerabang telur. Perlakuan tidak berpengaruh nyata terhadap kadar kalsium kerabang telur. Kesimpulan dari penelitian ini penambahan aditif dalam ransum berupa kombinasi kulit singkong dan Lactobacillus sp. dalam bentuk larutan dapat memperbaiki kualitas eksterior telur puyuh periode laying mulai pada taraf pemberian $100 \mathrm{ml}$ aditif/kg ransum.
\end{abstract}

Kata kunci : Puyuh, aditif, kulit singkong, Lactobacillus sp., kualitas eksterior telur.

\section{PENDAHULUAN}

Populasi peternakan puyuh di Indonesia saat ini terus meningkat, hal tersebut dikarenakan permintaan pasar yang terus menigkat dengan produksi telur puyuh berkisar antara 200 - 300 butir/tahun (Sugiharto, 2005), dewasa kelamin pada umur 40 - 41 hari dan bertelur pertama kali pada umur 45 hari. Puyuh memiliki masa bertelur selama $15-18$ bulan dan puncak produksi terjadi pada umur ke 3 - 5 bulan. Produksi telur rata-rata untuk satu populasi dapat mencapai $85 \%$ (Wuryadi, 2011). Kendala yang dialami peternak puyuh saat ini seperti harga pakan yang tinggi namun efisiensinya rendah. Cara yang digunakan untuk mengatasi masalah tersebut dengan cara penggunaan aditif berupa Antibiotic Growth Promotor (AGP) sintetis yang diklaim mampu meningkatkan produktifitas dan efisiensi ransum pada ternak puyuh. Namun saat ini antibiotik sintetis sudah dilarang penggunaannya karena 
residu yang dihasilkan pada produk yang diasilkan. Pelarangan antibiotik sintetis tersebut mengakibatkan banyak dilakukannya penelitian mengenai aditif pakan herbal yang dapat dijadikan alternatif sebagai pengganti antibiotik sintetis.

Aditif pakan merupakan bahan tambahan yang ditambahkan ke dalam ransum, beberapa jenis bahan aditif alami yang sering digunakan yaitu probiotik, prebiotik dan sinbiotik (Gülen $e t$ al., 2018). Prebiotik merupakan bahan aditif yang digunakan untuk menyuplai sumber makanan bagi suatu ekosistem probiotik. Limbah agroindustri yang melimpah di Indonesia berpotensi besar untuk dijadikan sumber prebiotik. Probiotik merupakan bahan aditif pakan yang berasal dari mikroorganisme hidup seperti Lactobacillus sp. dan Bifidobacterium yang tergolong bakteri asam laktat (BAL) / bakteri menguntungkan, dimana mikroorganisme yang dapat dikategorikan sebagai probiotik adalah mikroorganisme non-patogen dalam tubuh. Lactobacillus sp. merupakan sebuah hetegenus, tak berspora, berbentuk seperti tongkat, bakteri katalase gram positif negatif dan beberapa spesies umum digunakan sebagai probiotik karena dapat meningkatkan populasi mikroflora yang non-patogen di usus dan menekan mikroorganisme patogen (Otutumi et al., 2012).

Limbah kulit singkong merupakan salah satu limbah agroindustri yang cukup melimpah di Indonesia namun masih belum termanfaatkan secara optimal. Data tahun 2008 menyatakan bahwa produksi singkong Indonesia sebesar 20.794.929 ton (BPS, 2008) dengan persentase kulit sinkong yang dihasilkan 16\%, sehingga saat ini potensi ketersediaan kulit singkong bisa mencapai 3.327.188,6 ton/tahun. Kulit singkong mengandung serat kasar yang tinggi sehingga kurang disarankan untuk dijadikan sebagai bahan pakan bagi ternak unggas karena unggas merupakan hewan monogastrik yang kurang dapat mencerna serat kasar. Namun pada kulit singkong terdapat senyawa oligosakarida. Oligosakarida merupakan senyawa yang dapat dimanfaatkan untuk nutrisi Bakteri Asam Laktat (BAL) sebagai sumber energi (Haryati, 2011). Kulit singkong yang mengandung oligosakarida dapat dijadikan sebagai prebiotik, umumnya prebiotik berasal dari bahan pakan yang sukar dicerna, terdiri atas oligosakarida yang sulit tidak dapat dicerna termasuk fruktooligosakarida, galaktooligosakarida dan mannanoligosakarida (MOS), banyak penelitian yang telah membuktikan bahwa oligosakarida khususnya (MOS) memiliki kemampuan meningkatkan populasi bakteri non-patogen seperti bakteri asam laktat, menyebabkan tingkat keasaman saluran pencernaan meningkat kemudian menekan pertumbuhan bakteri patogen sehingga dapat memodulasi sistem imun, meningkatkan aktifitas enzim-enzim saluran yang dapat meningkatkan penyerapan nutrien (Güçlï, 2011)

Beberapa penelitian mengenai pemanfaatan probiotik dan prebiotik menunjukkan adanya perbedaan yang signifikan terhadap kualitas eksterior telur puyuh. Parameter yang dapat menentukan kualitas eksterior telur puyuh yaitu seperti bobot telur, tebal kerabang dan kadar kalsium dalam kerabang telur (Souza et al., 2016) Bobot telur yang dihasilkan dari adanya penambahan aditif dalam ransum menghasilkan bobot kisaran 9,74 - 10,24 g/butir (Sultana et al., 2007). Tebal kerabang telur puyuh yang diberikan aditif dalam ransum berupa probiotik dan prebiotik menghasilkan rerata tebal kerabang sebesar 0,356-0,373 $\mathrm{mm}$ (Shalaei et al., 2014) serta 0,12 - 0,14 mm (Amo et al. 2013). Kadar kalsium pada kerabang telur yang diberikan aditif menghasilkan kadar kalsium dalam kerabang telur sebesar 9,69\% (Yonata et al., 2017)

Penelitian ini bertujuan untuk mengetahui pengaruh pemberian aditif dalam ransum berupa kombinasi kulit singkong dengan Lactobacillus sp.dalam bentuk larutan terhadap kualitas eksterior telur puyuh pada fase laying. Manfaat yang diperoleh dari penelitian ini yaitu memperoleh informasi secara ilmiah mengenai efek pemberian aditif dalm ransum berupa kulit singkong dengan Lactobacillus sp. terhadap kualitas eksterior telur puyuh pada fase laying.

\section{MATERI DAN METODE}

Materi penelitian menggunakan 240 ekor puyuh petelur dari pembibitan desa Andong, Boyolali, Jawa Tengah. Puyuh dipelihara dalam kandang tipe lantai kawat bertingkat 3 , terdapat 12 kandang dengan ukuran $50 \times 45 \times 40 \mathrm{~cm}^{3} /$ kotak. Tiap unit percobaan berisikan 10 ekor puyuh betina. Penambahan aditif dalam ransum dimulai pada saat puyuh berumur 6 minggu. Pemberian ransum dilakukan dengan cara point feed 21 gram/ekor/hari, sedangkan air minum diberikan secara add libitum. Formula ransum berdasarkan kebutuhan puyuh untuk periode laying yang digunakan dalam penelitian ini disajikan pada Tabel 1. 
Tabel 1. Formula ransum puyuh layer

\begin{tabular}{|c|c|c|c|c|c|c|c|}
\hline \multirow{3}{*}{ Bahan Pakan } & \multirow{3}{*}{$\begin{array}{c}\text { Komposisi } \\
(\%)\end{array}$} & \multicolumn{6}{|c|}{ Ketersediaan Nutrien } \\
\hline & & \multirow[t]{2}{*}{$\begin{array}{c}\text { Energi } \\
\text { Metabolis } \\
\text { (kkal/kg) }\end{array}$} & $\begin{array}{c}\text { Protein } \\
\text { Kasar }\end{array}$ & $\begin{array}{c}\text { Lemak } \\
\text { Kasar }\end{array}$ & $\begin{array}{l}\text { Serat } \\
\text { Kasar }\end{array}$ & Kalsium & Phospor \\
\hline & & & \multicolumn{5}{|c|}{ 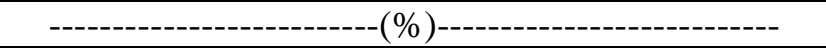 } \\
\hline Jagung kuning & 55 & 1826,55 & 4,89 & 2,20 & 3,41 & 0,11 & 0,13 \\
\hline Bekatul & 15 & 433,05 & 1,80 & 1,60 & 2,28 & 0,01 & 0,19 \\
\hline Bungkil kedelai & 13 & 288,08 & 5,78 & 0,14 & 0,57 & 0,04 & 0,07 \\
\hline Tepung ikan & 10 & 170,50 & 5,26 & 0,68 & 0,22 & 0,57 & 0,37 \\
\hline Premix & 2 & 7,91 & 0,01 & 0,04 & 0,01 & 0,20 & 0,03 \\
\hline $\mathrm{CaCO}_{3}$ & 5 & 0 & 0 & 0 & 0 & 1,95 & 0,01 \\
\hline Total & 100 & 2726,09 & 17,76 & 4,67 & 6,50 & 2,87 & 0,80 \\
\hline Kebutuhan & & 2700 & 17 & 7 & 7 & $2,5-3,5$ & $0,60-1,00$ \\
\hline
\end{tabular}

Keterangan : Bahan pakan berdasarkan kering udara.

Pembuatan aditif dilakukan dengan cara mencampur kulit singkong dengan Lactobacillus $s p$., kemudian mengisolasi bakteri asam laktat saluran pencernaan itik yang telah dimurnikan sehingga didapat isolat murni Lactobacillus $s p$.untuk kemudian diinkubator selama 1 x 24 jam, diperbanyak menjadi probiotik hingga didapatkan 2,3 $\times 10^{8} \mathrm{CFU} / \mathrm{ml}$, setelah itu hasil probiotik dapat disimpan dalam freezer bersuhu $18^{\circ} \mathrm{C}$ sehingga dapat bertahan selama 1,5 bulan, kemudian dilakukan percobaan taraf prebiotik yang harus ditambahkan untuk membentuk aditif yang sesuai, komposisi yang digunakan yaitu 100 $\mathrm{ml}$ aquades $+10 \%$ bakteri asam laktat (Lactobacillus sp.) dengan total bakteri 2,3 $\times 10^{8}$ $\mathrm{CFU} / \mathrm{ml}+$ taraf persentase prebiotik (tepung kulit singkong) yaitu masing-masing sebesar $4 \%, 5 \%$ dan $6 \%$. Berdasarkan percobaan yang telah dilakukan didapatkan hasil bawa kombinasi prebiotik $6 \%$ dapat memenuhi persyaratan untuk pengunaan aditif probiotik yang sesuai yaitu dapat mencapai $10^{7}-10^{8} \mathrm{CFU} / \mathrm{ml}$ (Sukarminah et al., 2017), hasil dari uji prebiotik terbaik diperoleh pada persentase prebiotik kulit singkong $6 \%$ dengan hasil mencapai $6,5 \times 10^{8}$ $\mathrm{CFU} / \mathrm{ml}$.

Parameter yang diamati meliputi berat telur, tebal kerabang, kadar kalsium kerabang telur. Pengamatan dilakukan sebanyak 2 kali dilakukan pada minggu ke-8 dan minggu ke- 13 dengan mengambil sampel sebanyak 2 butir telur puyuh untuk tiap unit percobaan. Pengambilan data untuk berat telur dilakukan dengan cara menimbang satu persatu sampel telur puyuh menggunakan timbangan digital dengan ketelitian 0,01 g. Pengambilan data untuk ketebalan kerabang dilakukan dengan cara kerabang telur dipisah dengan isi dan lapisan bagian dalam kemudian dikeringkan, kemudian diukur tiap-tiap telur pada 3 bagian kerabang, yaitu pada bagian ujung tumpul, tengah (ekuator), dan ujung lancip (Yuwanta, 2010) menggunakan mikrometer sekrup. Kerabang telur yang telah diukur ketebalannya kemudian digunakan untuk menguji kadar kalsium dalam kerabang telur di laboratorium dengan uji Abtomic Absorbtion Spectrophometer (AAS) untuk diketahui kadar kalsium yang terdapat dalam sampel kerabang (Kasiyati et al., 2010), data yang diperoleh pada tiap-tiap minggu dijumlah dan dirata-rata.

Rancangan penelitian ini menggunakan Rancangan Acak Lengkap (RAL) yang terdiri dari 4 perlakuan dengan 6 ulangan. Data yang telah diperoleh selanjutnya akan dianalisis menggunakan analisis sidik ragam (ANOVA) dengan uji lanjut wilayah ganda Duncan. Perlakuan yang diterapkan sebagai berikut :

T0 : Ransum basal tanpa penambahan aditif (kontrol)

T1 : Ransum basal + aditif $100 \mathrm{ml} / \mathrm{kg}$ ransum

$\mathrm{T} 2$ : Ransum basal + aditif $150 \mathrm{ml} / \mathrm{kg}$ ransum

T3 : Ransum basal + aditif $200 \mathrm{ml} / \mathrm{kg}$ ransum

\section{HASIL DAN PEMBAHASAN}

Berdasarkan hasil penelitian yang telah dilakukan didapatkan hasil penelitian yang disajikan pada Tabel 2. 
Tabel 2. Data hasil penelitian

\begin{tabular}{|c|c|c|c|c|}
\hline \multirow{2}{*}{ Parameter } & \multicolumn{4}{|c|}{ Perlakuan } \\
\hline & T0 & $\mathrm{T} 1$ & $\mathrm{~T} 2$ & T3 \\
\hline $\begin{array}{l}\text { Bobot telur } \\
\text { (g/butir) }\end{array}$ & $8,860 \pm 0,486^{\mathrm{c}}$ & $10,483 \pm 0,497^{\mathrm{ab}}$ & $10,812 \pm 0,793^{\mathrm{a}}$ & $10,113 \pm 0,311^{c}$ \\
\hline $\begin{array}{l}\text { Tebal kerabang } \\
\text { telur }(\mathrm{mm})\end{array}$ & $0,663 \pm 0,186^{\mathrm{b}}$ & $0,708 \pm 0,223^{\mathrm{a}}$ & $0,692 \pm 0,117^{\mathrm{a}}$ & $0,700 \pm 0,167^{\mathrm{a}}$ \\
\hline $\begin{array}{l}\text { Kadar kalsium } \\
(\%)\end{array}$ & $13,618 \pm 5,764$ & $13,736 \pm 6,182$ & $13,626 \pm 3,566$ & $13,959 \pm 3,025$ \\
\hline
\end{tabular}

Keterangan: Superskrip yang berbeda pada baris yang sama menunjukkan perbedaan nyata $(\mathrm{P}<0,05)$.

\section{Bobot Telur}

Berdasarkan hasil analisis statistik yang diperoleh, perlakuan berpengaruh nyata $(\mathrm{P} \leq 0,05)$ meningkatkan bobot telur. Bobot telur yang dihasilkan meliputi T0 : 8,860 g/butir; T1 : 10,483 g/butir; T2 : 10,812 g/butir dan T3 : $10,113 \mathrm{~g} /$ butir. Berdasarkan hasil yang diperoleh nilai rataan bobot telur lebih besar dari penelitian Sultana et al. (2007) 9,74-10,24 g/butir. (Zuhri et al., 2017) 8,01 - 8,68 g/butir. Menurut data yang diperoleh didapatkan hasil bahwa rataan bobot telur pada perlakuan T1,T2 dan T3 menunjukkan hasil yang lebih tinggi dibandingkan T0. Hal ini disebabkan karena adanya penambahan aditif pakan berupa kombinasi tepung kulit singkong dan Lactobacillus sp. dalam ransum. Pada perlakuan T1 sudah mampu meningkatkan bobot telur, hal ini diduga karena adanya penambahan aditif dalam ransum pada dosis $100 \mathrm{ml} / \mathrm{kg}$ ransum memiliki efektifitas yang sama dengan taraf pemberian perlakuan T2 yaitu $150 \mathrm{ml} / \mathrm{kg}$ ransum.

Pada penelitian Güçlü (2011) yang memanfaatkan penggunaan probotik dan prebiotik sebagai aditif pakan untuk ternak puyuh digunakan taraf pemberian prebiotik murni sebelum pengenceran $0,5-1 \mathrm{ml} / \mathrm{kg}$ ransum. Pada penelitian Otutumi et al. (2012) $0,5-1,5 \mathrm{ml} / \mathrm{kg}$ ransum probiotik murni sebelum pengenceran, memberikan pengaruh terhadap bobot telur dimana perlakuan tanpa pemberian probiotik lebih rendah dibandingkan dengan perlakuan kontrol dan tiap-tiap perlakuan memunculkan hasil yang berbeda pula dengan dosis pemberian probiotik yang berbeda. Pada penelitian ini menggunakan probiotik murni sebelum pengenceran sebanyak $10-15 \mathrm{ml} / \mathrm{kg}$ ransum.

Bobot telur yang meningkat dipengaruhi oleh faktor konsumsi ransum yang semakin meningkat, dengan meningkatnya konsumsi ransum maka sumber nutrisi untuk membentuk sebutir telur akan melimpah dan diharapkan kualitas dari telur yang dihasilkan juga akan semakin baik. Sesuai pendapat Amo et al. (2013) menyatakan bahwa konsumsi yang meningkat mengakibatkan meningkatnya bobot telur yang dihasilkan, hal ini disebabkan karena dalam ransum yang dikonsumsi terdapat nutrient yang diperlukan puyuh untuk dapat memproduksi telur setiap harinya, salah satu nutrient yang cukup berpengaruh dalam pembentukan telur ialah protein. Sesuai pendapat Zahra et al. (2012) bahwa konsumsi dapat mempengaruhi produktifitas serta kualitas telur yang dihasilkan puyuh, semakin rendah konsumsi ransum harian maka produktifitas dan kualitas dari telur yang dihasilkan juga semakin menurun.

Meningkatnya konsumsi ransum dipengaruhi oleh adanya penambahan aditif berupa probiotik bakteri asam laktat Lactobacillus $s p$., sehingga bobot telur yang dihasilkan juga meningkat, hal ini dikarenakan penambahan probiotik berupa bakteri asam laktat Lactobacillus sp., dapat meningkatkan daya cerna saluran pencernaan akibat peningkatan aktivitas enzim saluran pencernaan, disamping itu penambahan probiotik akan meningkatkan kesehatan, hal tersebut dikarenakan lingkungan saluran pencernaan yang lebih asam akibat penambahan bakteri asam laktat Lactobacillus $s p$. sehingga bakteri patogen dapat ditekan jumlahnya. Menurut Vali (2009) Efek positif dari penambahan probiotik Lactobacillus sp. dapat disebabkan oleh penurunan proliferasi bakteri patogen yang dihasilkan dari perubahan lingkungan usus dan peningkatan pemanfaatan nutrisi, penambahan probiotik Lactobacillus $s p$. juga dapat meningkatkan aktivitas enzimatik dalam saluran pencernaan yang berakibat meningkatkan pemanfaatan nutrisi berkat adanya efek positif dari suplementasi probiotik.

\section{Tebal Kerabang Telur}

Berdasarkan hasil analisis statistik yang diperoleh, perlakuan berpengaruh nyata $(\mathrm{P} \leq 0,05)$ meningkatkan tebal kerabang telur. Tebal kerabang telur yang dihasilkan meliputi T0 : $0,663 \mathrm{~mm}$; $\mathrm{T} 1: 0,708 \mathrm{~mm}$; T2 : 0,692 mm dan 
T3 : 0,700 mm. . Berdasarkan hasil rataan yang didapat, nilai tersebut lebih tinggi dari hasil penelitian sebelumnya untuk tebal kerabang telur puyuh yang diberikan aditif dalam ransum yaitu sebesar 0,356-0,373 $\mathrm{mm}$ (Shalaei et al., 2014) serta Amo et al. (2013) sebesar 0,12-0,14 mm. Menurut data yang diperoleh didapatkan hasil $\mathrm{T} 1, \mathrm{~T} 2$ dan $\mathrm{T} 3$ menunjukkan hasil yang lebih tinggi dibandingkan T0, hal ini disebabkan karena adanya penambahan aditif pakan berupa kombinasi tepung kulit singkong dan Lactobacillus sp. dalam ransum, namun hasil dari T1, T2 dan T3 tidak berbeda, hal ini diduga karena penambahan aditif dengan dosis yang terlalu tinggi sehingga hasil yang diperoleh memiliki rentang yang sedikit. Pada penelitian Güçlü (2011) yang memanfaatkan penggunaan probotik dan prebiotik sebagai aditif dalam ransum untuk puyuh hanya menggunakan taraf pemberian $50-100 \mathrm{ml} / \mathrm{kg}$ ransum.

Tebal kerabang yang berbeda dapat dipengaruhi oleh beberapa faktor seperti kadar kalsium dan bobot telur. Menurut Achmanu et al. (2010) bahwa kerabang telur sangat berkaitan dengan kadar kalsium yang terkandung didalamnya. bobot serta kadar kalsium yang tinggi disebabkan karena adanya penambahan aditif yang mengandung probiotik berupa bakteri asam laktat Lactobacillus sp., probiotik tersebut akan meningkatkan tingkat keasaman dalam saluran pencernaan sehingga aktivitas enzimatik dalam saluran perncernaan juga meningkat, dengan meningkatnya aktivitas enzimatik saluran perncernaan maka proses absorpsi nutrien akan maksimal.

Menurut Vali (2009) efek positif dari penambahan probiotik Lactobacillus sp. dapat disebabkan oleh penurunan proliferasi bakteri patogen yang dihasilkan dari perubahan lingkungan usus dan peningkatan pemanfaatan nutrisi, penambahan probiotik Lactobacillus sp. juga dapat meningkatkan aktivitas enzimatik dalam saluran pencernaan yang berakibat meningkatkan pemanfaatan nutrisi berkat adanya efek positif dari suplementasi probiotik. Meningkatnya absorpsi nutrien dari ransum yang dikonsumsi terutama mineral kalsium mengakibatkan peningkatan kualitas kerabang telur yang dihasilkan. Menurut Zuhri et al. (2017) yang menyatakan bahwa kalsium menjadi komponen terpenting dalam pembentukan kerabang telur, kerabang telur terbentuk saat fase gelap atau pada saat puyuh tidak aktif makan, kemudian sumber kalsium tersebut menjadi cadangan makanan dalam saluran pencernaan dan pada tulang rawan.

Tebal kerabang yang meningkat juga dapat dipengaruhi oleh faktor lain seperti asupan kalsium yang berpengaruh nyata $(\mathrm{P}<0,05)$. Asupan kalsium pada masing-masing perlakuan yaitu T0 $(0,464 \mathrm{~g})$; T1 $(0,522 \mathrm{~g})$; T2 $(0,529 \mathrm{~g})$ dan T3 $(0,519 \mathrm{~g})$ yang meningkat mengakibatkan proses pembentukan kerabang meningkat pula. Asupan kalsium (calcium intake) tersebut dipengarui oleh adanya probiotik sebagai aditif pakan, dimana mikroorganisme probiotik dapat memutus ikatan asam fitat yang terkandung dalam kulit singkong, dimana asam fitat tersebut bersifat mengikat mineral dalam ransum sehingga ketersediaan mineral dalam ransum berkurang, dengan adanya probiotik sebagai aditif pakan asam fitat yang terkandung dalam kulit singkong dapat diturunkan karena probiotik tersebut dapat mengaktifkan enzim fitase yang dapat mendegradasi fitat fosfor sehingga mineral dalam ransum dapat dicerna oleh ternak. Menurut Davis et al., (2008) dengan kondisi tertentu seperti $\mathrm{pH}$ yang semakin rendah dalam usus halus mengakibatkan hidrolisis fitat sehingga memungkinkan fitase aktif kemudian ikatan asam fitat akan longgar dan mineral seperti kalsium dan fosfor dapat dicerna.

\section{Kadar Kalsium Kerabang Telur}

Berdasarkan hasil analisis statistik yang diperoleh, perlakuan tidak berpengaruh nyata $(\mathrm{P} \leq 0,05)$ terhadap kadar kalsium kerabang telur puyuh. Menurut data yang diperoleh didapatkan hasil nilai rataan kadar kalsium kerabang telur puyuh yang tertinggi diperoleh pada T3 yaitu sebesar 13,959\%. Berdasarkan hasil rataan yang didapat, nilai tersebut lebih besar dibandingkan hasil penelitian sebelumnya. Menurut Yonata et al. (2017) kadar kalsium untuk kerabang telur puyuh sebesar 9,69\%.

Kadar kalsium yang tinggi diakibatkan oleh penambahan probiotik bakteri asam laktat Lactobacillus sp. yang menyebabkan konsumsi ransum meningkat, penambahan probiotik bakteri asam laktat Lactobacillus sp. dapat menurunkan $\mathrm{pH}$ saluran pencernaan sehingga menurunkan populasi bakteri patogen, meninkatkan aktivitas enzimatik saluran pencernaan dan melongarkan ikatan asam fitat dalam pakan, akibatnya kecernaan mineral seperti kalsium dan fosfor akan meningkat pula. Sesuai pendapat Arief et al. (2011) ikatan asam fitat yang terkandung dalam bahan pakan dari negara tropis dapat mengikat mineral-mineral yang terkandung dalam ransum 
sehingga mineral penting seperti kalsium dan fosfor terhambat penyerapannya, perlu adanya teknik pengolahan yang benar agar ikatan asam fitat melonggar seperti fermentasi oleh mikroba. Didukung Davis et al. (2008) dengan kondisi tertentu seperti $\mathrm{pH}$ yang semakin rendah dalam usus halus mengakibatkan hidrolisis fitat sehingga memungkinkan fitase aktif kemudian ikatan asam fitat akan longgar dan mineral seperti kalsium dan fosfor dapat dicerna.

Kadar kalsium dalam kerabang telur dipengaruhi oleh asam amino esensial yang diperoleh dari pakan yang tercerna, semakin banyak asam amino esensial yang tercerna maka akan semakin banyak pula material kalsium yang dapat tercerna. Hal ini disebabkan adanya ikatan $\mathrm{CaBP}$ yang terjadi secara siklik. Menurut Maharani et al. (2013) kalsium dan protein khususnya protein sitosolik merupakan komponen yang saling bergantung satu sama lain, interaksi dari komponen tersebut membuat suatu siklus antara protein dengan kalsium, dimana kalsium memerlukan asam amino esensial untuk menunjang pembentukan hormon paratiroid yang berperan dalam metabolisme kalsium, dan kalsium diperlukan oleh protein untuk menaktifkan enzim proteolitik atau yang sering disebut dengan Calcium Activated Neutral Protease (CANP). Menurut Saraswati (2017) transfer kalsium bekerjasama dengan sintesis protein sistolik yang kerap disebut Calcium Binding Protein $(\mathrm{CaBP})$ yang ditemukan pada glandula tubuler sebagai tempat terjadinya tranport kalsium dengan adanya enzim Ca-ATPase pada uterus, dimana enzim tersebut sebagai absorptor kalsium dalam cairan uterus.

Faktor lain yang mempengaruhi kadar kalsium dalam kerabang yaitu kandungan kalsium pada kerabang serta dengan adanya suasana asam yang meningkat dengan adanya pemberian aditif Lactobacillus sp. dalam ransum dapat meningkatkan solubilitas $\mathrm{CaCO} 3$ pakan dan meningkatkan retensi kalsium saluran cerna. Menurut Saraswati (2017) peningkatan sekresi asam dan air pada proventrikulus dapat meningkatkan solubilitas kalsium karbonat dalam pakan sehingga retensi kalsium intestinum saat kalsifikasi kerabang telur meningkat.

Disamping itu jumlah kalsium yang terkandung dalam ransum dapat mempengaruhi deposisi kalsium pada kerabang karena kalsium tidak hanya digunakan untuk pembentukan tulang akan tetapi kalsium juga digunakan untuk mengikat protein yang digunakan dalam pembentukan telur dengan adanya siklus $\mathrm{CaBP}$.
Menurut Kasiyati et al. (2010) menyebutkan bahwa pada saat puyuh sudah berproduksi telur, pada bagian tubuh skeletonnya 98\% adalah kalsium hidroksiapatit $\left(\mathrm{Ca} 10\left(\mathrm{PO}_{4}\right) 6(\mathrm{OH}) 2\right)$, kalsium fosfat nonkristalik dan $\mathrm{CaCO} 3$, periode aktif pembentukan telur pada puyuh terjadi pada siang hari akan lebih banyak memanfaatkan kalsium dalam ransum yang dikonsumsi kalsium dalam tulang medular akan digunakan sebagai cadangan kalsium pembentuk kerabang apabila pada saat siang hari sumber kalsium yang digunakan sebagai pembentuk kerabang terdefisiensi, akan tetapi tulang medular masih tetap dipergunakan untuk menyediakan kalsium diawal deposisi pembentukan kerabang.

\section{KESIMPULAN}

Penambahan aditif dalam ransum berupa kombinasi kulit singkong dan Lactobacillus $s p$. dalam bentuk larutan dapat memperbaiki kualitas eksterior telur puyuh periode laying yang meliputi bobot telur, tebal kerabang serta kadar kalsium kerabang telur. Penambahan aditif dalam ransum berupa kombinasi kulit singkong dan Lactobacillus $s p$. dalam bentuk larutan dapat diberikan pada taraf $100 \mathrm{ml} / \mathrm{kg}$ ransum.

\section{DAFTAR PUSTAKA}

Achmanu, Muharlien dan Salaby. 2011. Pengaruh lantai kandang (rapat dan renggang) dan imbangan jantan-betina terhadap konsumsi pakan, bobot telur, konversi pakan dan tebal kerabang pada burung puyuh. J. Ternak Tropika 12 (2) : 1-14.

Amo, M., J. L. P. Saerang, M. Najoan dan J. Keintjem. 2013. Pengaruh penambahan tepung kunyit (Curcuma domestica Val) dalam ransum terhadap kualitas telur puyuh (Coturnix-coturnix japonica). ZOOTEC 33(1) : 48-57.

Arief, R. W., I. Irawati dan Yusmasari. 2011. Penurunan Kadar Asam Fitat Tepung Jagung Selama Proses Fermentasi Menggunakan Ragi Tempe. Balai Pengkajian, Teknologi Pertanian Lampung. Prosiding. (Seminar Nasional Serealia). Hal: 590-597.

Davis, A. K., D. L. Maney and J. C. Maerz. 2008. The use of leucocytes profiles to measure 
stress in vertebrates: a review for ecologists. Functional Ecology. 22: 760772 .

Güçlü, B. K. 2011. Effects of prebiotic and prebiotic (Mannan oligosaccharide) supplementation on performance, egg quality and hatchability in quail breeeders. Ankara Üniv Vet Fak Derg. 58: 27-32.

Gülen, S. and I. Coşkun. 2018. Dietary or in ovo Saccharomyces cerevisiae suplementation developed growth, caecal microbiota and gut histology of broiler chicks. Turkish Journal of Agriculture-Food Science and Technology 6 (7) : 863-868.

Kasiyati, N. Kusumorini, H. Maheswari dan W. Manalu. 2010. Kajian fisiologis status kalsium puyuh (Coturnix coturnix japonica) setelah pemberian cahaya monokromatik. Buletin Anatomi dan Vali, N. 2009. Probiotic in quail nutrition : a Fisiologi 1 (17) : 1-11.

Otutumi, L. K., M. B. Gois, E. R. M. Garcia and M. M. Loddi. 2012. Variation on the efficacy of probiotics in poultry. IntechOpen Chapter $9:$ 203-230.

Saraswati, T. R. 2017. Absorpsi dan metabolisme kalsium pada puyuh (Coturnix-coturnix japonica). Buletin Anatomi dan Fisiologi 2 (2) : 178-186.

Shalaei M., S. M. Hosseini and E. Zergani. 2014. Effect of different supplements on eggshell quality, some characteristics of gastrointestinal tract and performance of laying hens. Veterinary Research Forum 5 (4) : 277-286.

Souza, D. S., L. F.L. Calixto, M. J. Lemos, C. A. S. Filho, T. P. Pinho, C. A. Machado, I. A. Melo and C. K. Togashi. 2016. Quail performance and egg quality at the end of production fed with varying levels of calcium. Seminaro Ciências Agrárias, Londrina, 37 (4) : 2395-2406.

Sugiharto, R. E. 2005. Meningkatkan keuntungan beternak puyuh. Agromedia Pustaka, Jakarta.

Sukarminah, E., E. Mardawati, E. Wulandari, Y. Cahyana dan B. D. Ningsih. 2017. Pengaruh konsentrasi tepun sorgum (Sorgum bicolor L. Moench) terhadap beberapa karakteristik minuman sinbiotik. Asian Journal of Environtment, History and Heritage 1 (2) : 1-11.

Sultana, F. M. S. Islam and M. A. R. Howlider. 2007. Effect of dietary calcium sources and levels on egg production and eggshell quality of Japanese quail. J. of Poultry Science 6 (2) : 131-136. review. Int. J. of Poultry Science 8 (12) : 1218-1222.

Yonata, D., S. Aminah dan W. Hersoelistyorini. 2017. Kadar kalsium dan karaktreristik fisik tepung cangkang telur unggas dengan perendaman berbagai pelarut. J. Pangan dan Gizi 7 (2): 82-93.

Zahra, A. A., D. Sunarti dan E. Suprijatna. 2012. Pengaruh pemberian pakan bebas pilih (Free choice feeding) terhadap performans produksi telur burung puyuh (Coturnix coturnix japonica). Animal Agriculture Journal 1(1) : 1-11.

Zuhri, M. A., E. Sudjarwo dan A. A. Hamiyanti. 2017. Pengaruh pemberian tepung bawang putih (Allium sativum L) sebagai feed additive alami dalam pakan terhadap kualitas eksternal dan internal telur pada burung puyuh (Coturnix coturnix japonica). Maduranch 2 (1) : 23-30. 